\title{
Pengaruh Tingkat Pengetahuan dan Sikap Ibu terhadap Konsumsi Obat Cacing pada Murid Sekolah Dasar MI DDI Gusung Kota Makassar
}

\author{
Santriani Hadi ${ }^{1}$ IIma Khaerina Amaliyah B. ${ }^{2}$, Nurfachanti Fattah ${ }^{3}$, Nur \\ Fitriany Lihawa ${ }^{4 *}$ \\ ${ }^{1,3}$ Departemen Parasitologi, Fakultas Kedokteran, Universitas Muslim Indonesia \\ ${ }^{2}$ Departemen Farmakologi, Fakultas Kedokteran, Universitas Muslim Indonesia \\ ${ }^{4}$ Departemen Program Studi Sarjana Kedokteran Fakultas Kedokteran, Universitas Muslim Indonesia \\ *Email Korespondensi: santrianidewa@gmail.com Telp: 082271111694
}

\begin{abstract}
ABSTRAK
Latar belakang:. Infeksi cacing yang ditularkan melalui tanah adalah salah satu infeksi paling umum di seluruh dunia. Infeksi cacing dapat berdampak pada tingkat kecerdasan dan produktivitas. Ibu merupakan garis terdepan dalam tahap pencegahan cacingan pada anak yang salah satu perannya adalah memastikan anak mengonsumsi obat cacing secara rutin. Penelitian ini bertujuan untuk mengetahui Pengaruh Tingkat Pengetahuan dan Sikap Ibu terhadap Konsumsi Obat Cacing pada Murid Sekolah Dasar MI DDI Gusung. Sampel penelitian adalah ibu dari murid SD Kelas 1,2 dan 3 MI DDI Gusung Kota Makassar.

Metode: Penelitian merupakan penelitian observasional analitik dengan rancangan cross sectional. Penelitian ini dilakukan di MI DDI Gusung Kota Makassar pada bulan Maret - April 2019. Populasi dalam penelitian ini adalah ibu dari murid di MI DDI Gusung Periode Maret 2019 dan sampel yang diambil adalah ibu dari murid SD kelas 1, 2 dan 3 di MI DDI Gusung Kota Makassar Periode Maret 2019.

Hasil: Hasil penelitian menunjukkan bahwa responden dengan pengetahuan baik memiliki persentase lebih tinggi (66.7\%) dalam mengonsumsi obat cacing secara rutin dibandingkan responden dengan pengetahuan kurang $(0 \%)$. Hasil uji statistik chi-square didapatkan $\mathrm{p}=0.000$ yang berarti terdapat hubungan antara tingkat pengetahuan dengan konsumsi obat cacing. Untuk variabel sikap menunjukkan bahwa responden dengan sikap yang baik memiliki persentase lebih tinggi $(47.5 \%)$ dalam mengonsumsi obat cacing secara rutin dibandingkan responden dengan sikap kurang (33.3\%). Hasil uji statistik chi-square didapatkan $\mathrm{p}=0.019$, ini menunjukkan bahwa terdapat hubungan antara sikap dengan konsumsi obat cacing.
\end{abstract}

(Berlanjut halaman selanjutnya)

Article history:

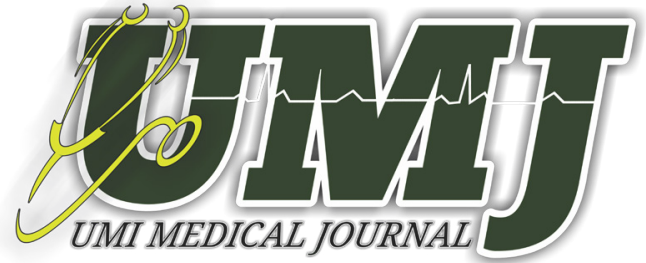

Received: 1 May 2020

Accepted: 23 June 2020

Publish Online: 30 June 2020

Published By :

Fakultas Kedokteran

Universitas Muslim Indonesia

Phone:

$+6282293330302$
Address:

J1. Urip Sumoharjo Km. 5 (Kampus II UMI)

Makassar, Sulawesi Selatan.

Email:

medicaljournal@umi.ac.id 
(Lanjutan halaman sebelumnya)

Kesimpulan: Terdapat hubungan antara tingkat pengetahuan dan sikap ibu terhadap konsumsi obat cacing pada murid sekolah dasar MI DDI Gusung Kota Makassar.

Kata kunci: Obat cacing; infeksi cacing; anak.

\begin{abstract}
Background: Soil worm infections are one of the most common infections in the entire world. Worm infections can affect the level of intelligence and productivity. The mother is the forefront in the prevention stage of intestinal worms in children, one of which is to ensure that children consume worm medication regularly. This study aims to determine the effect of the level of knowledge and attitudes of mothers to the consumption of worm medicine in elementary students of MI DDI Gusung. The research sample is the mother of elementary school students in Class 1.2 and 3 MI DDI Gusung Makassar City.

Method: The study was an observational analytic study with a cross sectional design. This research was conducted in MI DDI Gusung Makassar City in March - April 2019. The population in this study was the mother of students in MI DDI Gusung in the March 2019 period and the samples taken were mothers of elementary school students grades 1, 2 and 3 in MI DDI Gusung Makassar City Period March 2019.

Results: The results showed that respondents with good knowledge had a higher percentage $(66.7 \%)$ in taking worm medicine regularly than respondents with less knowledge $(0 \%)$. Chi-square statistical test results obtained $\mathrm{p}=0.000$, which means there is a relationship between the level of knowledge with the consumption of worm medicine. The attitude variable shows that respondents with a good attitude have a higher percentage (47.5\%) in consuming worm medicine routinely than respondents with a less attitude (33.3\%). Chi-square statistical test results obtained $p=0.019$, this shows that there is a relationship between attitude and consumption of worm medicine. Conclusion: There is a relationship between the level of knowledge and attitudes of mothers towards the consumption of worm medicine in elementary students of MI DDI Gusung Makassar City.
\end{abstract}

Keywords; Worm medicine; worm infection; child. 


\section{PENDAHULUAN}

Infeksi cacing yang ditularkan melalui tanah adalah salah satu infeksi yang paling umum di seluruh dunia. Meskipun cacingan jarang menyebabkan kematian langsung, namun cacingan merupakan salah satu penyebab anemia gizi dan berdampak pada tingkat kecerdasan dan produktivitas. Cacingan yang berat dan menahun juga terbukti mempengaruhi pertumbuhan, perkembangan fisik, dan mental anak-anak serta berdampak pada gangguan kemampuan belajar. ${ }^{1}$

Menurut World Health Organization (WHO), pada tahun 2015 lebih dari 600 juta anak usia sekolah tinggal di daerah dimana parasit ini ditularkan secara intensif, dan membutuhkan pengobatan serta intervensi pencegahan. Sedangkan, pada tahun 2017, WHO memperkirakan lebih dari 1,5 miliar orang atau 24\% dari populasi dunia terinfeksi oleh cacing yang ditularkan melalui tanah. ${ }^{2}$

Di Indonesia, penyakit cacing adalah penyakit yang umum dan infeksinya dapat terjadi secara bersamaan oleh beberapa jenis cacing sekaligus. Menurut Direktur Pengendalian Penyakit Bersumber Binatang (P2B2) Kementerian Kesehatan, pada tahun 2015, angka prevalensi cacingan meningkat di atas 20\% dengan prevalensi mencapai 28,12\%.3 Sedangkan, pada tahun 2017, berdasarkan Lampiran Peraturan Menteri Kesehatan Nomor 15 Tahun 2017 tentang Penanggulangan Cacingan menyebutkan, prevalensi cacingan di Indonesia bervariasi antara $2,5 \%$ hingga $62 \%$. Jumlah ini meningkat bila prevalensi cacingan dihitung pada anak usia sekolah, prevalensinya menjadi $80 \%{ }^{4}$

Sulawesi Selatan adalah salah satu provinsi di Indonesia yang menjadi perhatian masyarakat karena potensi yang dimiliki dalam bidang perikanan, perdagangan, ekonomi dan pariwisata. Namun, hal lain yang menjadi perhatian adalah tingginya kasus cacingan di wilayah Sulawesi Selatan. Berdasarkan data dari Dinas Kesehatan Kabupaten/Kota bahwa Kota Makassar menjadi kota tertinggi penderita kasus cacingan. Jumlah penderita cacingan di Kota Makassar berdasarkan laporan Dinas Kesehatan Kabupaten/Kota mengalami peningkatan dari tahun 2013 (3.226 kasus), 2014 (3.266 kasus), 2015 (3.270 kasus). ${ }^{5}$

Data dari Puskesmas Tabaringan bulan Januari 2019 saat melakukan pemeriksaan cacingan di MI DDI Gusung dan MDIA Paotere menemukan bahwa dari 49 sampel pada murid SD usia 5-14 tahun terdapat 20 orang positif cacingan atau sebanyak 40,81\%.6 Tingginya prevalensi yang ada menyebabkan diperlukannya pencegahan cacingan.

Berdasarkan Pedoman Pencegahan Cacingan, Ibu merupakan garis terdepan dalam tahapan pencegahan cacingan. Peran ibu terdiri dari mengajarkan anak untuk mencuci tangan pakai sabun, menggunakan air bersih untuk keperluan rumah tangga, menjaga kebersihan dan keamanan makanan, mengupayakan kondisi lingkungan yang sehat, serta konsumsi obat cacing secara teratur, misalnya 3 atau 6 bulan sekali sesuai resep dokter.7 Berdasarkan hal tersebut, jika ibu tidak menyadari pentingnya menjaga kebersihan pada anaknya, maka anak akan mudah terinfeksi penyakit cacingan.

Obat cacing oral sangat efektif dalam membunuh sebagian besar jenis cacing dengan hanya satu dosis. Adanya infeksi ulang yang cepat berarti bahwa obat tersebut harus diminum setiap 6-12 bulan sekali untuk mencegah infeksi ulang, sehingga menemukan pendekatan yang berkesinambungan dalam pemberian obat merupakan isu yang mendesak. ${ }^{8}$ 
Dengan dasar ini, penulis berinisiatif untuk menganalisis pengaruh tingkat pengetahuan dan sikap ibu terhadap konsumsi obat cacing pada murid sekolah dasar. Tujuan penelitian ini adalah untuk mengetahui pengaruh tingkat pengetahuan dan sikap ibu terhadap konsumsi obat cacing pada murid sekolah dasar MI DDI Gusung Kota Makassar.

\section{METODE}

Penelitian merupakan penelitian observasional analitik dengan rancangan cross sectional. Penelitian ini dilakukan di MI DDI Gusung Kota Makassar pada bulan Maret - April 2019. Populasi dalam penelitian ini adalah ibu dari murid di MI DDI Gusung Periode Maret 2019 dan sampel yang diambil adalah ibu dari murid SD kelas 1, 2 dan 3 di MI DDI Gusung Kota Makassar Periode Maret 2019. Variabel dalam penelitian terdiri dari variabel independen yaitu tingkat pengetahuan dan sikap ibu serta variabel dependen yaitu konsumsi obat cacing pada murid sekolah dasar.

Pengambilan sampel penelitian dilakukan secara total sampling. Berdasarkan cara memperoleh data, data yang dikumpulkan adalah data primer. Data primer diperoleh dengan cara kunjungan ke MI DDI Gusung. Pengolahan data dilakukan secara elekronik dengan menggunakan perangkat lunak komputer program Microsoft Excel 2010 dan SPSS 23 - for windows. Kemudian melakukan analisis data dengan dua cara yaitu dengan analisis univariat untuk mendeskripsikan data secara sederhana dan analisis bivariat untuk mengetahui hubungan antara dua variabel yaitu variabel dependen dan independen. Dalam melakukan penelitian perlu membawa rekomendasi dari institusi oleh pihak lain dengan cara mengajukan permohonan izin kepada institusi / lembaga tempat penelitian yang dituju oleh peneliti. Setiap subjek akan dijamin kerahasiannya atas informasi yang diperoleh dari data sekunder dengan tidak menuliskan identitas subjek dalam penelitian melainkan hanya menggunakan inisial untuk penamaan.

\section{HASIL}

Penelitian dilakukan dengan mengunjungi lokasi penelitian yaitu MI DDI Gusung Kota Makassar. Penelitian dilakukan dengan terlebih dahulu menjelaskan kepada responden tentang pentingnya mengonsumsi obat cacing secara rutin pada anak. Setelah itu, dilakukan pembagian kuesioner penelitian dan menjelaskan kepada responden tata cara pengisian kuesioner dan menjawab pertanyaan responden ketika ada pertanyaan yang kurang difahami. Setelah itu, kuesioner dikumpulkan dan dilakukan pengolahan data menggunakan Microsoft Excel 2010 dan data yang telah dikumpulkan dilakukan uji statistik dengan perangkat lunak SPSS 23 - for windows.

Rutinitas konsumsi obat cacing pada anak berdasarkan kategori usia, pendidikan terakhir dan kelas dari responden dapat dilihat pada tabel 1 . 
Tabel 1 Distribusi Frekuensi Responden Berdasarkan Karakteristik

\begin{tabular}{cccccc}
\hline \multirow{2}{*}{ No } & Kategori & \multicolumn{5}{c}{ Konsumsi Obat Cacing pada Anak } \\
& & $\mathrm{n}$ & $\%$ & $\mathrm{n}$ & $\%$ \\
\hline 1 & Usia Ibu & & & & \\
& $21-30$ & 5 & 23.8 & 5 & 13.5 \\
& $31-40$ & 8 & 38.1 & 18 & 48.6 \\
& $41-50$ & 7 & 33.3 & 11 & 29.7 \\
& $>50$ & 1 & 1.0 & 3 & 8.1 \\
\hline 2 & JUMLAH & 21 & 100 & 37 & 100 \\
\hline & Pendidikan Terakhir & & & & \\
& SD & 3 & 14.3 & 24 & 64.9 \\
& SMP & 6 & 28.6 & 7 & 19.0 \\
& SMA & 8 & 38.1 & 6 & 16.2 \\
& S1 & 4 & 19.0 & 0 & 0 \\
\hline 3 & JUMLAH & 21 & 100 & 37 & 100 \\
\hline & Kelas & & & & \\
& 1 & 5 & 23.8 & 11 & 29.7 \\
& 2 & 9 & 42.9 & 13 & 35.1 \\
& 3 & 7 & 33.3 & 13 & 35.1 \\
\hline & JUMLAH & 21 & 100 & 37 & 100 \\
\hline
\end{tabular}

Berdasarkan tabel 1, usia responden yang anaknya mengonsumsi obat cacing secara rutin adalah responden dengan usia 31-40 tahun $(38,1 \%)$ dan tidak mengonsumsi obat cacing secara rutin adalah responden usia 31-40 tahun (48,6\%). Adapun pendidikan terkahir responden yang mengonsumsi obat cacing secara rutin adalah SMA $(38,1 \%)$, dan pendidikan terakhir responden yang tidak mengonsumsi obat cacing adalah SD $(64,9 \%)$. Sedangkan, untuk kategori kelas yang mengonsumsi obat cacing secara rutin adalah kelas 2 (42,9\%) dan yang tidak mengonsumsi obat cacing secara rutin adalah kelas 2 dan $3(35,1 \%)$.

Analisa bivariat dilakukan dengan uji statistic chi-square untuk mengetahui hubungan antara tingkat pengetahuan dan sikap ibu terhadap konsumsi obat cacing murid sekolah dasar. Hubungan tingkat pengetahuan terhadap konsumsi obat cacing pada murid sekolah dasar dapat dilihat pada tabel 2. 
Tabel 2 Hasil Uji Chi-Square Hubungan Tingkat Pengetahuan dengan Konsumsi Obat Cacing

\begin{tabular}{|c|c|c|c|c|c|c|}
\hline & \multirow{2}{*}{ Variabel } & & \multicolumn{2}{|c|}{ Konsumsi Obat Cacing } & \multirow{2}{*}{ Jumlah } & \multirow{2}{*}{ Nilai $p$} \\
\hline & & & Ya & Tidak & & \\
\hline \multirow{6}{*}{ Pengetahuan } & \multirow{2}{*}{ Kurang } & $\mathrm{n}$ & 0 & 17 & 17 & \multirow{6}{*}{0.000} \\
\hline & & $\%$ & $0.0 \%$ & $100.0 \%$ & $100.0 \%$ & \\
\hline & \multirow{2}{*}{ Cukup } & $\mathrm{n}$ & 1 & 10 & 11 & \\
\hline & & $\%$ & $9.1 \%$ & $90.9 \%$ & $100.0 \%$ & \\
\hline & \multirow{2}{*}{ Baik } & $\mathrm{n}$ & 20 & 10 & 30 & \\
\hline & & $\%$ & $66.7 \%$ & $33.3 \%$ & $100.0 \%$ & \\
\hline
\end{tabular}

Tabel 2 menunjukan hasil uji statistik dengan chi-square antara variabel tingkat pengetahuan dengan konsumsi obat cacing nilai $\rho$ sebesar 0,000 . Karena nilai $\rho<0,05$ yaitu 0,000 , maka terdapat hubungan antara pengetahuan dan konsumsi obat cacing pada anak.

Sedangkan, hubungan antara sikap terhadap konsumsi obat cacing pada murid sekolah dasar dapat dilihat pada tabel 3 .

Tabel 3 Hasil Uji Chi-Square Hubungan Sikap dengan Konsumsi Obat Cacing

\begin{tabular}{|c|c|c|c|c|c|c|}
\hline & \multirow{2}{*}{ Variabel } & & \multicolumn{2}{|c|}{ Konsumsi Obat Cacing } & \multirow{2}{*}{ Jumlah } & \multirow{2}{*}{ Nilai $\mathbf{p}$} \\
\hline & & & Ya & Tidak & & \\
\hline \multirow{6}{*}{ Sikap } & \multirow{2}{*}{ Kurang } & $\mathrm{n}$ & 1 & 2 & 3 & \multirow{6}{*}{0.019} \\
\hline & & $\%$ & $33.3 \%$ & $66.7 \%$ & $100.0 \%$ & \\
\hline & \multirow{2}{*}{ Cukup } & $\mathrm{n}$ & 1 & 14 & 15 & \\
\hline & & $\%$ & $6.7 \%$ & $93.3 \%$ & $100.0 \%$ & \\
\hline & \multirow{2}{*}{ Baik } & $\mathrm{n}$ & 19 & 21 & 40 & \\
\hline & & $\%$ & $47.5 \%$ & $52.5 \%$ & $100.0 \%$ & \\
\hline
\end{tabular}

Tabel 3 menunjukan hasil uji statistik dengan chi-square antara variabel sikap ibu dengan konsumsi obat cacing nilai $\rho$ sebesar 0,019 . Karena nilai $\rho<0,05$ yaitu 0,019 , maka terdapat hubungan antara sikap ibu dengan konsumsi obat cacing pada murid sekolah dasar.

\section{PEMBAHASAN}

\section{Hubungan Tingkat Pengetahuan terhadap Konsumsi Obat Cacing pada Murid Sekolah Dasar}

Hasil penelitian menunjukkan, dari 58 responden terdapat 17 responden yang memiliki pengetahuan kurang, 11 responden dengan pengetahuan cukup dan 30 responden dengan pengetahuan yang baik mengenai konsumsi obat cacing. Dari data hasil penelitian menunjukkan bahwa, responden dengan pengetahuan yang baik memiliki frekuensi lebih tinggi dalam mengonsumsi obat cacing secara rutin dibandingkan responden dengan pengetahuan yang kurang. 
Hal ini membuktikan bahwa seiring peningkatan pengetahuan seseorang terhadap konsumsi obat cacing, terjadi pula peningkatan konsumsi obat cacing secara rutin.

Melalui hasil analisa data, dapat dikatakan bahwa terdapat hubungan antara tingkat pengetahuan dengan konsumsi obat cacing pada murid sekolah dasar. Penemuan ini sesuai dengan hasil penelitian oleh Liani (2012) yang menemukan bahwa ibu-ibu PKK dengan tingkat pendidikan lanjutan di Kecamatan Tepus Kabupaten Gunungkidul memiliki pengetahuan yang baik mengenai konsumsi obat cacing sebanyak 76,9\%. ${ }^{9}$

Hasil penelitian Nizar (2016) juga menemukan bahwa terdapat hubungan antara konsumsi obat pencegahan filariasis di Desa Berancah Wilayah Upt Puskesmas Selatbaru tahun 2016 dengan hasil uji statistic p value $\leq 0,05(\mathrm{p}$ value $=0.000)$. Penelitian ini menemukan bahwa 132 responden yang berpengetahuan baik mengonsumsi obat filariasis $(67 \%)$ dan 52 responden berpengetahuan tidak baik tidak mengonsumsi obat filariasis $(82,5 \%) .^{10}$

Hasil penelitian Agus (2016) juga menemukan bahwa terdapat hubungan antara tingkat pengetahuan tentang filariasis dengan konsumsi obat pencegah filariasis dengan hasil $p<0,05(p \text { Value }=0,000)^{11}$

\section{Hubungan Sikap terhadap Konsumsi Obat Cacing pada Murid Sekolah Dasar}

Hasil penelitian menunjukkan, dari 58 responden terdapat 3 responden dengan sikap kurang, 15 responden dengan sikap cukup dan 40 responden dengan sikap baik mengenai konsumsi obat cacing. Dari data hasil penelitian menunjukkan bahwa responden dengan sikap yang baik memiliki frekuensi lebih tinggi dalam mengonsumsi obat cacing secara rutin dibandingkan responden dengan sikap yang kurang. Dapat dilihat bahwa seiring peningkatan sikap seseorang terhadap konsumsi obat cacing, terjadi pula peningkatan konsumsi obat cacing secara rutin. Hasil penelitian menunjukkan, dari 58 responden terdapat 3 responden dengan sikap kurang, 15 responden dengan sikap cukup dan 40 responden dengan sikap baik mengenai konsumsi obat cacing. Dari data hasil penelitian menunjukkan bahwa responden dengan sikap yang baik memiliki frekuensi lebih tinggi dalam mengonsumsi obat cacing secara rutin dibandingkan responden dengan sikap yang kurang. Dapat dilihat bahwa seiring peningkatan sikap seseorang terhadap konsumsi obat cacing, terjadi pula peningkatan konsumsi obat cacing secara rutin.

Melalui hasil analisa data, dapat dikatakan bahwa terdapat hubungan antara sikap dengan konsumsi obat cacing pada murid sekolah dasar. Penelitian ini didukung dengan penelitian yang dilakukan oleh Liani (2012) yang menemukan gambaran sikap ibu-ibu PKK Kecamatan Tepus Kabupaten Gunungkidul terhadap konsumsi obat cacing sebanyak 60\%. ${ }^{9}$

Hal ini juga didukung dengan penelitian yang dilakukan oleh Nizar (2017) mengenai hubungan tingkat pengetahuan dan sikap kepala keluarga dengan mengonsumsi obat pencegahan filariasis di Desa Berancah Wilayah Upt Puskesmas Selatbaru Tahun 2016, yang menemukan adanya hubungan antara sikap dengan konsumsi obat dengan $\mathrm{p}$ value $<0,05(\mathrm{p}=0,000)$. Penelitian ini menemukan bahwa 94 responden bersikap positif mengonsumsi obat filariasis $(67 \%)$ dan 49 responden yang bersikap negatif tidak mengonsumsi obat filariasis $(38,3 \%) .{ }^{10}$ 


\section{KESIMPULAN}

Terdapat tingkat hubungan antara tingkat pengetahuan dan sikap ibu terhadap konsumsi obat pada murid sekolah dasar MI DDI Gusung Kota Makassar

\section{DAFTAR PUSTAKA}

1. Zulkoni, A. Parasitologi. Nuha Medika; 2011.

2. WHO. World Health Organization Fact Sheets: Soil-Transmitted Helminth Infections. 2017. Available at: http://www.who.int/mediacentre/factsheets/fs366/en/\%0A. (Accessed: 27th March 2018)

3. Octama CI. Angka Prevalensi Cacingan di Indonesia Mencapai 28,12 Persen. Beritasatu (2015). Available at: http://www.beritasatu.com/kesra/319918-angka-prevalensi-cacingan-di-indonesia-mencapai-2812persen.html. (Accessed: 27th March 2018)

4. Menteri Kesehatan Republik Indonesia. Peraturan Menteri Kesehatan Republik Indonesia Nomor 15 Tahun 2017 Tentang Penanggulangan Cacingan. in 17-19 (2017).

5. Amaliah ATR \& Azriful. Distribusi spasial kasus kecacingan (Ascaris lumbricoides) terhadap personal higiene anak balita di Pulau Kodingareng Kecamatan Ujung Tanah Kota Makassar Tahun 2016. J. Epidemiol. 2016; 4(1):74-80.

6. Petugas Surveilans Puskesmas Tabaringan. Kasus Cacingan Puskesmas Tabaringan Menurut Kelurahan Bulan Januari 2019: 2019.

7. Menteri Kesehatan Republik Indonesia. Surat Keputusan Menteri Kesehatan RI. in Bab II: Cacingan. 2017. p.22-23.

8. Jameel AL. Buletin Kebijakan: Deworming (Pembasmian Cacing) Pilihan Terbaik untuk Penanganan. Poverty Action Lab 1; 2012.

9. Liani FF. Swamedikasi Cacingan pada Ibu-ibu PKK di Kecamatan Tepus Kabupaten Gunungkidul (Kajian Pengetahuan dan Sikap). 2012. p.20.

10. Hamidi MNS \& Asmawati. Hubungan Pengetahuan dan Sikap Kepala Keluarga Tentang Filariasisi Dengan Mengonsumsi Obat Pencegahan Filariasis Di Desa Berancah Wilayah Upt Puskesmas Selatbaru Tahun 2016. FIK Univ. Pahlawan Tuanku Tambusasi Riau Indones. 2017; 1(1): 57-73.

11. Alamsyah, A. Cakupan Menelan Obat Massal Pencegah Filariasis. J. Endur. 2016; 1(2):17-22. 